\title{
Economics Perspectives on the Entrepreneurial Decision
}

\begin{abstract}
The pervasiveness of the entrepreneurial phenomenon draws scholars' attention as to what determines the decision to become an entrepreneur. Entrepreneurial decisions imply judgemental decisions. Different approaches in economics conceive judgemental decisions as firm entry, or real investment in the creation of a new business, or making a career choice in favour of a particular type of self-employment. The literature on entrepreneurs' features, motives and markets is then enriched with theoretical and empirical results from industrial organization, financial economics and labour economics.
\end{abstract}

Keywords: Entrepreneurial decision, Entry, Real investment, Self-employment. JEL classification: D21, D81, J23, G11.

\section{Introduction and motivation}

Since Schumpeter (1954) defined an entrepreneur as "the pivot on which everything turns", research into entrepreneurship has grown rapidly. Many surveys and reviews have been written about entrepreneurship especially in the last twenty years (e.g., Casson, 1990; Gartner, 1990; Bull and Willard, 1996; Glancey and McQuaid, 2000; Storey, 2000; Swedberg, 2000; Westhead and Wright, 2000; Audretsch, 2002; Acs and Audretsch., 2003; Casson, 2003; Shane, 2003; Casson, 2006; Casson, 2010) and a huge number of conferences, 
workshops and debates have been devoted to this topic. However, despite this prominent role in "both popular culture and the historical record" (Casson, 2003), both twentieth-century mainstream economic theory and modern economic textbooks fail to adequately integrate entrepreneurship into economic theory.

As Bygrave and Hofer (1991) observe, “A major challenge facing entrepreneurship researchers in the 1990s is to develop models and theories built on solid foundations from the social sciences.” Although economics is the logical discipline in which a theory of entrepreneurship should emerge, the entrepreneur has rarely been studied within the context of the basic neoclassical framework of economics. Brock and Evans (1989) note that “Economists have concentrated overwhelmingly on large businesses”. The leading textbooks in economics have little or no discussion of small businesses or entrepreneurs” (Eisenhauer, 1995). Mainstream economic theory takes the existence of markets as given and regards competition as an impersonal process (XX) where the wholesale price coordinates supply and demand, or where they are adjusted by an auctioneer, or where new firms enter when extra profits are available and exit as soon as they have been eroded. In such a framework, “entrepreneurs disappear from view” (Casson, 2003). When entrepreneurs are eliminated from the market process, buyers and sellers must interact directly with each other; however, in practice, in most markets they are relatively passive. In the real world, it is entrepreneurs who publish price quotations and compete most intensely with each other;: buyers and sellers simply choose from the "menus" provided by the entrepreneurs. Furthermore, when entrepreneurs are eliminated from the market process, economists tend to regard firms as producers who do not even decide on when to enter the market. ${ }^{1}$ As a result, the knowledge exploited by firms is assumed to relate to production technology, whereas in fact it relates mainly to supply and demand.

\footnotetext{
${ }^{1}$ It is the presence of extra profits that provokes entry.
} 
Managerial studies on entrepreneurship have built on the need to improve upon this role of mere coordinator where the entrepreneur is far from being a decision-maker. A number of studies explicitly developed for entrepreneurship began to explore this issue further by looking at personal traits and delineating the peculiarities of an entrepreneur with respect to other economic agents: attitude in coping with risk (Cantillon, 1759) or uncertainty (Knight, 1921), alertness (Kirzner, 1983), creativeness (Schumpeter, 1942; 1954), imagination (Shackle, 1970). It is assumed that the entrepreneurial decision is stimulated not by the expectation of maximizing wealth depending on the characteristics of a temporary disequilibrium of the market, but as an individual manifestation of specific attitudes: these traits may be linked to agents’ preferences such as risk attitudes or ability in making use of information.

Next, a bunch of models (e.g. Casson, 1982; Campbell, 1992) tried to link the roles of personal features and of external economic conditions related to specific industries (like the type of occupation, location, wages and human capital) and modelled the entrepreneurial decision by assuming that the expected reward of entrepreneurship is compared to the best alternative use of time by the potential entrepreneur. The total costs related to the entrepreneurial decision cover both actual money costs (i.e. venture capital) and psychological costs like the "fear of personal embarrassment and loss of self-esteem, and the potential fear of having to find alternative employment”.

Casson (1982; 2003) provides a further attempt at synthesizing these issues in a coherent and general model where an entrepreneurial function is identified as common to all approaches: this is the exercise of judgement in decision-making. The essence of judgement is the following: "where there is no obvious decision rule, and no readily available source of public information, different people will use different procedures to arrive at a given decision and will therefore act differently in the same situation” (XX). The entrepreneurial 
act becomes something more than the carrying out of new combinations: it requires the ability to evaluate opportunities, which is not common to everybody.

This idea of judgemental decision puts the grounds for going beyond canonical thinking as it focuses very sharply on the nature of judgement. This allows us to study the entrepreneur by examining, among others, the factors influencing the demand and supply of judgement, the characteristics and peculiarities that entrepreneurs should demonstrate as judgemental decision-makers, the motivational aspect behind the decision in favour of a job where judgemental decisions are part of the every-day agenda, and the role of profits or rents in rewarding judgement. Furthermore, we believe this concept opens up the possibility of finding some useful insights about the entrepreneurial decision from other branches of economic theory. We argue that the failure of economists to integrate the entrepreneur into economic theory could be not absolute if we consider the possible meanings that the entrepreneurial “judgemental” decision assumes. From an industrial organization point of view, the entrepreneurial decision corresponds to a firm's entry into an industry. Recent contributions to the theory of the firm discuss the relations between entrepreneurs, firms, industries and markets, and these insights can be used to investigate how entrepreneurial judgemental decisions are shaped by industry specificities, through information, level of competition, degree of maturity and so on.

From a financial point of view, the entrepreneurial decision represents a specific case of real business investment. Here, judgemental decisions concern aspects like the optimal type and timing of such a real investment and the evaluation of alternative investment opportunities.

Finally, from a labour economics perspective the entrepreneurial decision is the result of a specific career choice in favour of a form of self-employment characterized by judgemental decisions. 
This paper aims to widen the implications of considering the entrepreneurial decision as a judgemental decision. The entrepreneur can be alternatively depicted as a newcomer, a (real) investor or a (self-employed) worker and the discussion considers not only economic studies that explicitly speak of entrepreneurship, but also works on strictly related phenomena. To be complete, a synthetic theory of the entrepreneurial decision needs to account for all those contributions that proficiently integrate the comprehension of the entrepreneurial role(s) and function(s). The aim is to develop a theory that encompasses these strands of literature by appropriately defining the term of entrepreneur and some basic assumptions on entrepreneurial motives, traits, and environment.

\section{The entrepreneurial decision as an "entry" decision}

The industrial organization literature conceptualizes the entrepreneurial decision as "entry" of a new firm into a market. More specifically, Mueller (1991) refers to a "firm that supplies a product within an industry without having supplied it previously”. As seen above, traditional industrial economics models reflect the neoclassical attitude of emphasizing this decision as playing a re-equilibrating function: when an industry demonstrates extra profits with respect to long-term market equilibrium (where entry does not occur), new firms come in and "erode" these rents. The probability of entry is negatively affected by the presence of barriers that might prevent potential entrants from exploiting profitable market opportunities and allow incumbent firms to earn super profits. Thus, it is industry characteristics, in terms of both industry profitability and the level of structural or behavioural barriers, that determines or not a firm's entry decision. In mainstream entry models, firms are assumed to be homogeneous with respect to their cost functions and to the amount of information they are provided with. As discussed above, the market is exogenously given and new-entrant 
firms make decisions that cannot be classified as judgemental because they represent only a coordination act.

Nonetheless, more recent entry models emphasize the issues of information and judgement, opening up an active role of entrepreneurs in driving the entry decision. A key concern regards the interplay between information characteristics and the specificity of the industry where the entrepreneurial decision takes place, and the moment when it occurs.

The concept of "technological regime" (Nelson and Winter, 1982) devotes attention to the technological attributes of the industrial environment: appropriability of the innovative rents, cumulativeness of technological advance, level of technological opportunities and characteristics of knowledge. The features of the entry process cannot be generalized across different industries: some technological conditions favour entry more than others, as the industry might evolve in a direction that widens the spectrum of available opportunities and competences required or deepens existing ones. Analogously, Audretsch (1995) suggests two possible models describing industry evolution: the "revolving door" that captures high turbulence and difficulty in surviving (and corresponds to Nelson and Winter's "routinized regime”), and the "metaphor of the forest” where new entrants displace established firms that grounded their roots in the industry and force them to exit (as in the "entrepreneurial regime”).

Studies on the industry life cycle (e.g. Jovanovic and MacDonald, 1994; Klepper, 1996) emphasize the importance of considering the specific stage of evolution of the industry. Grounding on previous works by Abernathy and Utterback (1978), this kind of analysis stresses that entry is much easier in the early stages of evolution: a radical innovation gives birth to a new industry, entry barriers are low and product innovations frequent. As the industry evolves toward maturity, output grows considerably, the number of versions of the product decline and more investment is devoted to process innovation: 
barriers to entry become significant, entry rates decrease and a shakeout occurs in the number of producers.

Another group of models in industrial organization explicitly focuses on the role of information and uncertainty in affecting the entry decision. The essence of the decision to enter lies in firms' willingness to discover their own true efficiency level that determines the probability of surviving and prospering. A model in which uncertainty represents a key ingredient in the explanation of entry is suggested by Jovanovic (1982): firms do not know exactly how good their own capabilities are: by means of a mechanism of "noisy selection", some of them are discovered to be more efficient than others, survive and prosper while less efficient ones decline and exit. Firms in this case are no longer "black boxes", but entrepreneurs who do make judgemental decisions and whose performance depends on the evolution and maturity not only of the decision-maker, but of the industry and/or the environment as well.

In a similar way, the model described by Horvath et al. (2001) shows the relevance of uncertainty and information disclosure in determining entrants' decisions. After observing other firms' performances, potential entrants reduce their uncertainty: the greater the number of firms in the market, the broader the information available to potential entrants and the higher the frequency of entry choices that is governed by a self-reinforcing mechanism.

Therefore, many recent contributions in industrial organization can successfully contribute to modelling the entrepreneurial decision by pointing out that: (1) the entrepreneurial decision is a judgemental decision in so far as only entrepreneurs can deal with information idiosyncratically related to an industry and to the specific moment when entry should take place. Industrial organization theories that account for these aspects find higher confirmation in data about entry. Furthermore, (2) recent contributions in industrial economics have tried to integrate the analysis of entry determinants related to the industrial 
structure with an investigation of the biases and limitations that can affect firms' decisions, in a perspective that exhibits some similarities with attention towards personal traits in entrepreneurship theory. Potential entrants' expectations of success determine entry choice, but these expectations may be affected by mistakes that concern one's own abilities and probability of success. Individual suboptimality can still drive the market to optimality, but individual and social welfare analyses should be carried out separately. The most famous contribution is represented by Camerer and Lovallo's (1999) paper that stresses the importance of overconfidence in leading the entry decision and shows that entrants can predict the number of competitors correctly, but are unable to evaluate their performance with respect to their peers. Not only do they overestimate their capabilities, but also seem to reason as if they were alone in the competitive arena ("reference group neglect" phenomenon). This work opened up a strand of literature that involves psychological insights in understanding the entry decision (e.g. Moore and Cain, 2005; Moore et al., 2007; Hogarth and Karelaia, 2010). Several studies show how entrepreneurs' failures in intuitive reasoning may play a role in the findings of a number of recent studies in entrepreneurship. Entrepreneurs seem to be affected by cognitive biases like those qualified as heuristics by Kahneman et al. (1982). Cooper et al. (1988), among others, show that entrepreneurs perceive their prospects for success as substantially better than those of similar businesses. Moreover, their degree of optimism appears to be higher if they have already made the commitment to become business owners: the theory of cognitive dissonance studies decision-makers' attitudes to bolster or exaggerate the attractiveness of an option after it has been chosen (Abelson and Levi, 1985).

Thus, the determinants of entry should concern not only the features of the industry where it takes place (observed in a specific moment), but also the way in which entrants frame their decisions and the possible distortions affecting them. 


\section{The entrepreneurial decision as an "investment" decision}

A few works (since the seminal work by Dixit, 1989 and in more recent papers like O'Brien, et al., 2004; Grenadier and Wang, 2007; Das et al., 2007) belonging to the financial area conceptualize the entrepreneurial decision as a particular case of real business investment. Investment is usually a macro concept, studied at an integrated level: in elementary macroeconomic models, the private investment flow plays a crucial role in connecting real markets and monetary markets. Aggregate investment depends on an individual firm's choice: since in orthodox neoclassical theories macroeconomics and microeconomics are not distinctly different disciplines, analysing macroeconomic investment is analytically identical to analysing microeconomic investment, because both theories describe the profitmaximizing behaviour of firms balancing their marginal costs and benefits.

If a firm can instantaneously and inexpensively adjust its capital stock, then - as in Jorgenson’s (1963) work - its decision about how much capital to use is a static decision where the marginal product of capital is equated to the user cost of capital. The investment literature, however, has emphasized the presence of two types of friction: adjustment costs and irreversibility. The adjustment cost literature (since the contribution by Eisner and Strotz, 1963) assumes the adjustment cost function to be strictly convex and have a value of zero at zero investment. In the 1970s and 1980s, this literature merged with the literature on Tobin's $q$ (Tobin, 1969), that is centred on the fact that the optimal rate of investment is an increasing function of the ratio of the firm's market value and the replacement cost of the firm’s capital. Mussa (1977) and Abel (1982) argued that the optimal rate of investment is the rate that equates the marginal adjustment cost to the marginal value of installed capital (marginal $q$ ).

On the other hand, the fact that investment might be irreversible represents another type of friction affecting the investment decision. Irreversibility makes investment especially 
sensitive to various forms of risk, such as uncertainty over future product prices and operating costs that determine cash flows, uncertainty over future interest rates, and uncertainty over the cost and timing of the investment itself. An investment is made a sunk cost by the fact that capital is firm- or industry-specific, so that it cannot be used productively elsewhere. Dixit (1989) investigates entry (and exit) decisions as forms of investment (and disinvestment) that occur in an environment characterized by uncertainty. Hysteresis, defined as the failure to reverse an effect when its causes have been reverted, is the main feature in this setup. Pindyck (1991) and Dixit and Pyndick (1994) emphasize the analogy between real and financial investment decisions and conceptualize the opportunity of making an irreversible investment as a call option on a stock that consists of the capital in place. Standard financial economics techniques are used to find the "price of the option” (i.e. the value of the entry opportunity for the firm) and the rule concerning the "optimal timing of exercising the option” (i.e. the optimal timing of entering) after which the option to enter is "killed": the investor gives up the possibility of waiting for new information that might influence the appeal of this investment itself. Performing an irreversible investment in the creation of a new firm when payoffs are stochastic means sacrificing the option to invest in the future: to maximize profits, therefore, “one must balance the profits foregone by delaying entry against the option value relinquished when entry has occurred” (Lambrecht and Perraudin, 2003). This might imply that the optimal entry timing tends to occur later than the first date when the present discounted value of future cash flow exceeds zero. Intuition suggests that an idle firm will enter when demand conditions become sufficiently favourable, and an active firm will abandon [the market] when they become sufficiently adverse. Dixit (1989) shows that the optimal strategy for this kind of investment and abandonment will take the form of two threshold prices. In most real-world situations, the demand and cost 
conditions a firm faces change all the time, and the firm must make its entry and exit decisions taking into account that the future is uncertain.

Among recent contributions in this field, O’Brien et al. (2004) provide not only an empirical test of the influence of irreversibility on an entrepreneur's sensitivity to uncertainty, but also advance theory by proposing that the irreversibility of entrepreneurial entry decisions may be influenced by industry, firm, and even individual level factors. Consistent with predictions derived from real options theory, this paper shows that high uncertainty in the target industry dissuades entry, and that the irreversibility of the entry decision moderates this relationship.

Huisman et al. (2003) deal with the effects of strategic interactions on the option value of waiting associated with investments under uncertainty. Whereas the real option literature mainly considers intrinsic uncertainty that will always exist regardless of a firm having invested or not, their contribution investigates another kind of uncertainty, which is uncertainty that reduces because of information that becomes available over time. A key feature of the latter kind of uncertainty is that the information is imperfect, and we believe this is the type of uncertainty that arises when judgemental decisions occur. For example, when a new communication technology is introduced and the entrepreneur opens such a new market, there will always be uncertainty about the demand for the new service, depending on the business cycle, the unemployment rate and so on. On the other hand, there is uncertainty about the level of structural demand for the new service. With the help of market research the entrepreneur could gain more insight into structural demand, which decreases uncertainty. Since a marketing survey consists of a sample and not an entire population, the signals that it provides on the profitability of an investment are imperfect.

In brief, according to the option theory approach, when framing the entrepreneurial decision as an investment decision new insights can be derived on the judgements 
entrepreneurs have to make. The investment decisions are not sufficiently alike or recur sufficiently often to warrant the development of routine procedures. Since their information requirements are difficult to anticipate in advance, the appropriate strategy is to concentrate responsibility for a decision on a suitable individual, i.e. the entrepreneur. He collects information from different sources in order to make a risky decision (Casson, 2003).

Again, it is the information that entrepreneurs can acquire by observing an uncertain environment - like price reflecting supply or demand conditions - that turns out to be crucial in determining an entrepreneurial decision and stimulating it at a specific moment. Thus, when the entrepreneurial decision is explicitly analysed, and framed as an investment decision, contextual factors related to information play a major role: framing the entrepreneurial decision as an investment decision implies that the opportunity cost of founding a new venture takes into account alternative forms of investment of the corresponding amount of money (e.g. real estate, bond, equities and so on).

\section{The entrepreneurial decision as a "self-employment" decision}

The literature in labour economics has devoted a lot of effort into investigating the entrepreneurial decision that has been conceptualized as “self-employment”. 'Entrepreneur' became the favoured appellation for anyone who was self-employed or a small-scale employer; even economists got in on the act, and described anyone who chose selfemployment as an alternative to unemployment or waged employment as an 'entrepreneur' (Blanchflower and Oswald, 1998). Since Osborne (1976), these works have depicted the entrepreneurship decision as involving the choice between two income streams: a rational individual can decide to accept a waged position earning a certain amount of money per year, or go into business with the anticipation of receiving a share of profits. 
According to the definition prevailing in labour-market statistics, self-employment does not correspond exactly to entrepreneurship because the self-employed are not necessarily innovative entrepreneurs pursuing growth-enhancing business projects. However, the two phenomena can be considered equivalent with a good level of approximation: also the literature shows some overlap. As emphasized above, we believe the difference lies in the fact that the entrepreneur is specialized in making choices that require an intensive use of judgement (Casson and Wadeson, 2007b).

The approach based on labour economics reinterprets the entrepreneur opportunity cost in terms of alternative uses of time and leisure more than liquidity and shows how motivational factors might become crucial when the entrepreneurial decision is perceived as a career choice. The proliferation of econometric works investigating the determinants of self-employment was motivated by the sharp increase in self-employment that occurred in Europe, the United States and Canada in the 1970s and 1980s, after a downward trend that had persistently characterized the period 1910-1970 (Fairlie and Meyer, 2000). This stylized fact strongly suggests that a fundamental change had occurred in advanced industrial economies that made self-employment more attractive.

Possible explanations have initially concerned the presence of changes in an industrial structure; price shifts in favour of industries where self-employment was relatively common; rising marginal tax rates in a context where the ease of underreporting income is higher for self-employment; increased wage rigidity that rationed a proportion of paid workers out of waged jobs; rising real retirement benefits that enabled higher flexibility and “partial retirement”.

Parker (1996) summarizes these explanations into two categories: the first views selfemployment as the outcome of adverse conditions in the paid employment sector ("recession push" theories); the second emphasizes the presence of pull factors like lower tax rates, 
greater ease of hiring and firing and "rejuvenated entrepreneurial spirit" in the supply side of the economy (Hughes, 1992). Both push and pull theories consider the returns from selfemployment as being of central importance and have been recently discussed by Schjoedt and Shaver (2007).

Hamilton (2000) classifies models explaining the self-employment choice that were based on the assumption of wealth maximization in three categories. First, investment and agency models (e.g. Lazear, 1981; Lazear and Moore, 1984) claim that self-employment differentials derive from differences in earning profiles across sectors. While the expected present value of self-employment income is equal to the paid employment alternative for the marginal worker, a cross-sectional earning differential may exist as a result of sectoral differences in earnings or in the experience profile due to patterns of career earnings' growth in paid and self-employment. The investment model argues that the self-employment earning profile will be steeper than for those in paid employment because human and capital investment are not shared with an employer in self-employment; agency models explain the steeper earning profiles of paid employment, referring to the need to discourage shirking since agency problems are not present in self-employment.

Second, matching and learning models (e.g. Roy, 1951; Jovanovic, 1982) emphasize that earning differences arise from differences in sector-specific abilities. Individuals have unobserved, time-invariant, sector-specific abilities and human capital: earning differential therefore may reflect selection effects that cause workers to choose the sector where they have a relative advantage (individuals may know immediately in which sector they fit best or, because of uncertainty, they may need some time to decide), and low-ability entrepreneurs are expected to drop out of self-employment.

Third, "superstar" theory (Rosen, 1981) argues that the comparison between selfemployment and paid work can be significantly influenced by a handful of high income 
entrepreneurial superstars. Small differences in skills might be magnified into large disparities in returns in the labour market characterized by imperfect substitution among different sellers and in which the costs of production do not rise in the same proportion to the size of a seller's market. MacDonald (1988) demonstrates that, as in the learning models, workers who realize they are not "rising stars" tend to return to paid employment.

Although these models focus on the pecuniary motives of entrepreneurial choice and have generally shown a good explanatory power, expected monetary earnings can turn out to be insufficient for clarifying choice in favour of self-employment and especially of entrepreneurship. As Hamilton (2000) emphasizes, differences in non-pecuniary aspects may lead to compensating earning effects for equally productive workers. A popular view is that entrepreneurship offers a higher level of freedom in the work environment that can be translated into the possibility of being “one’s own boss”. Evans and Leighton (1989) show that individuals preferring higher autonomy are more likely to become self-employed. Conversely, Kanbur (1982) emphasizes the role of risk-aversion in the self-employment decision: business owners may earn a risk premium because of a higher uncertainty in their earnings. Risks may have a temporal structure, so that the entrepreneurial decision is influenced by impatience levels: by entering a risky activity an agent can acquire information about his ability, which is useful for future occupational choice. In equilibrium, risk-taking has the characteristics of postponed gain relative to the safe alternative, so that in an environment with lower time rates of discount more risk-taking activities will be observed. These explanations based on love for freedom/autonomy, risk-seeking preference and patience present several features in common with the idea of personal traits in entrepreneurship theory. Still drawing upon Knight’s (1921) notion that individuals respond to risk-adjusted relative earnings, Rees and Shah (1986) carried out an exhaustive empirical work with the aim of throwing further light on the binary choice between self-employment 
and paid work: self-employment has been shown to be generally regarded as being more risky since, on average, the coefficient of variation of self-employment earnings is over three times that of paid-employment earnings. Another important determinant, however, is given by the nature of the work involved. The attractions of self-employment are the flexibility and independence entailed; on the other hand, self-employment usually implies a greater number of working hours and a higher level of responsibility, so that it can be mentally and physically more demanding. Moreover, education affects the choice primarily by reducing the coefficient of variation in self-employment earnings: in fact, education serves as a filter such that the more educated are more likely to be uniform in their abilities; furthermore, they tend to be better informed, implying a greater efficiency when assessing self-employment opportunities. Concerning the influence of age, data show that there is a tendency for employees to switch to self-employment towards the end of their working life as an alternative to retirement (Quinn, 1980); however, the old can be less likely to take risks than the young. Health is expected to affect self-employment through work characteristics: longer hours and greater responsibility imply that the less healthy might find self-employment status too demanding.

Eisenhauer (1995) claims that the decision to become an entrepreneur may be viewed as an occupational choice motivated by economic factors: an individual is assumed to decide to undertake a new venture if it is expected to make him or her better off. The individual utility function is generally defined by wealth (consisting of two components: existing net assets and the present value of future income) and working conditions and increases in both. An individual perceives a latent consumer demand for a good and sees the opportunity to launch a new venture. Subjective estimates of revenues and costs are formulated; a venture is worthwhile if the utility of venturing exceeds the utility of not venturing. The difference between the present values of venture and non-venture incomes can be interpreted as an 
expected risk premium. As empirical studies indicate that risk aversion declines as wealth rises (e.g. Szpiro, 1986), the risk premium necessary to induce an entrepreneurial decision will be smaller the greater the value of initial wealth. This suggests that success in entrepreneurship, by increasing wealth, can reduce the entrepreneur's degree of risk aversion, and encourage more venturing. Entrepreneurship may therefore be a self-perpetuating process. Moreover, if the venture conditions are preferable to working conditions in the wage sector, then a venture may be acceptable even if the risk premium is negative; this may explain Gunderson's (1990) idea that most new businesses are "life-style choices” where the likelihood that the income will be less than that derived from a comparable effort working for someone else is compensated by other kinds of returns. On the other hand, certainty has a negative value for risk-seeking individuals: Brockhaus (1980) provides evidence that at least some entrepreneurs demonstrate mild risk-loving behaviour, but in general there is no clear result of this correlation. Douglas and Shepherd (2002) describe entrepreneurs in terms of the strength or weakness of their attitudes toward income, independence, risk, and work effort and investigated the effect these attitudes have on the intention to start one's own business, finding that the strength of intention to become self-employed is significantly related to a respondent's tolerance for risk and preference for independence.

If personal attitudes towards risk and autonomy appear to be crucial in determining the choice of self-employment, a further assumption is needed when we speak of entrepreneurship. Entrepreneurs are aware that everyday life and work will be concerned with judgemental decisions: they feel sufficiently confident to deal with them everyday and look for this type of stimulus. Entrepreneurs have a comparative advantage in collecting and processing information, such that they succeed in recognizing opportunities: when new scarcities arise, opportunities emerge to economize on the scarcer resources and entrepreneurs are encouraged to seek out those projects which help the economy to adapt to 
changing conditions (Casson and Wadeson, 2007b). This skill in processing information can be regarded as one of the components of human capital: "It is not the routine managerial skill of taking decisions according to procedures, but rather the skill of judging what these procedures should be. It is also the skill involved in taking decisions in unexpected business situations where ordinary procedures do not apply” (XX). From this perspective, entrepreneurship is one of a number of inputs that contributes to the overall performance of the economy. Together with the other components of human capital - skilled manual labour and routine management - it may be considered as a factor input into the economy that improves the allocative efficiency of the economy (ibidem).

In brief, theories in labour economics frame the entrepreneurial choice as a career choice, and this argument has strong implications in terms of the attention that is devoted to motivational aspects of the decision. The interest in personal characteristics recalls the idea of the importance of personal traits in entrepreneurship theory. Here, personality features are interpreted more explicitly as engines of entrepreneurial choice and involve complex considerations on what is needed to make judgemental decisions and on how judgemental decisions affect motivations.

\section{A synthesis}

The sections above have shown how economic theories may differ in defining the entrepreneur, his motives and characteristics, and the environment in which he operates. What clearly emerges is that "it is difficult to encapsulate all the insights of the theory of entrepreneurship into a single model” (Casson and Wadeson, 2007a). A major challenge when arranging the theoretical framework to an encompassing model is to fix straightforward but sufficiently general assumptions to "do justice to the heterogeneity of the economy” (ibidem). Furthermore, this paper faces the additional challenge of constructing 
assumptions that could be useful for models of entrepreneurship in different strands of the literature: industrial organization, real business investment, labour economics.

\subsection{Defining the entrepreneur}

When modelling the entrepreneurial decision we need first to define what is an entrepreneur. The choice of the definition grounds on the specific research questions scholars are concerned with and on the objectives of the model. According to Casson (1982), there are four main approaches to defining an entrepreneur, which emphasize respectively function, role, personal characteristics and behaviour. As argued above, we define the entrepreneur according to his function, which then determines his role: he is specialized in taking a “judgemental decision”. However, this definition might be insufficient in stressing flair, imagination and creativity and "there is the need for constructing a theory that will predict a pattern of behaviour that appears creative and imaginative” (Casson and Wadeson, 2007a). This lies in the ability to recognize and exploit opportunities and correctly predict the demand for novelty. Differently from other decision-makers involved in firm life, the entrepreneur's function consists of internalizing the "market for newly-discovered opportunities” (ibidem).

Economic theories discussed in the previous sections account for several forms of judgemental decisions: consequently, the entrepreneur has to deal with a specific type of uncertainty that is related to the context where the decision takes place and to the way in which the decision is framed, and this shapes the opportunity cost of being an entrepreneur. The uncertainty the entrepreneur has to face regards market entry into a specific industry, the investment process, or the career course. Whether judgement affects the creation of a new market or entry into an established one, the entrepreneur has to acquire information on the industry (its stage of development, maturity, level of competition, and so on) and the 
competitors, and evaluate the opportunity costs of operating in a different industry or not entering the new market. When judgement regards the profitability or convenience of choosing a real investment, the entrepreneur has to acquire and administer information about alternative types of investment (for instance, in bonds or equities or real estate) and about the timing of when it is optimal to spend the option. When judgement is about an entrepreneur's own career, uncertainty concerns not only personal attitudes and satisfaction in preferring self-employment, but also wage and rent conditions. Thus, our focus on judgemental decision succeeds in constructing a definition that enables us to account for an entrepreneur who operates as a new entrant, as a real business investor and as a self-employed worker. Further specifications depend on which branch of economic theory the model belongs to.

\subsection{Assumptions on characteristics}

The definition discussed above implies that the entrepreneur has a peculiar ability for recognizing opportunities and facing non-measurable uncertainty. The subjectivity of opportunities explains why some people recognize opportunities where other people do not (Loasby, 1976). Opportunities need to be discerned because they are not clearly labelled and it is the entrepreneur that has the talent to make this judgemental decision. Although situational and personality measures have been shown to fail to significantly predict entrepreneurial activity (Krueger et al., 2000), empirical observation suggests that imagination, creativity and the attitude to deal with uncertain scenarios are common features in individuals who decide to become entrepreneurs. Which assumptions on rationality derive from the entrepreneur's attitude towards the discovery of opportunities and uncertainty?

Following Casson and Wadeson (2007b), we assume that entrepreneurs are "metarational”, in the sense that they optimize the amount of information they collect. This implies that they face a trade-off between the costs of collecting additional information and the 
benefit of reducing the risk of a mistake (i.e. missing a profitable opportunity, or exploiting an unprofitable opportunity by confusing it with a profitable one). The amount of uncertainty entrepreneurs face depends on their own decisions on how much information to collect: if they are willing to pay an information cost to widen their knowledge on market, competitors, industries, personal abilities and so on, they can process additional information. The scarcity of information is addressed by economizing on its use: collecting the whole amount of information required to guarantee the correct decision would be too expensive. Meta-rational individuals are "instrumental and purposeful" in the sense that they pursue given ends (Mises, 1949), but they are only "boundedly rational” rather than "substantively rational”, in the sense that they do not normally act upon full information (Simon, 1983). Thus, we assume entrepreneurs as boundedly rational individuals who demonstrate a particular ability for processing costly information on industries, markets, competitors and personal attitudes with the aim of reducing uncertainty.

\subsection{Assumptions on motives}

The central role of judgemental decisions in the entrepreneur's acts affects the assumptions on the motives and reasons behind the choice of becoming an entrepreneur. Two key issues arise: why do individuals decide to become entrepreneurs? What is the nature of entrepreneurial reward?

From a private point of view, the immediate purpose of exploiting an opportunity is to make a profit. Opportunity recognition, stimulated by the prospect of profit, encourages entrepreneurs to seek out the projects which help the economy to adapt to changing conditions: since Kirzner (1973), it is the prospect of profit from an opportunity that motivates the search that leads to discovery. As the economy adapts to changing conditions, new opportunities arise as fast as others are destroyed: the exploitation of opportunities is a 
vital part of the economy as a response to external shocks. As seen above, the view that agents would choose activities yielding the highest private returns comes naturally to industrial organization, financial and labour economists. More specifically, as entrepreneurs deal with judgemental decisions, entrepreneurs' profit can be interpreted as a premium for the uncertainty within the judgement.

Besides these considerations on pecuniary motives, the judgemental nature of the entrepreneurial decision moves the attention onto the need for satisfying some non-pecuniary desires, e.g. for status or self-esteem or other personal needs. If the decision is judgemental, motives are no longer only pecuniary (see above the discussion on self-employment models) but based on the need for facing such a type of decision. The ends pursued by entrepreneurs may be non-materialistic: some choices offer them emotional rewards, based on personal recognition and social status (the will to win) and the chance of creating a legacy (the desire to found a dynasty).

Furthermore, there is another perspective to account for. From a social point of view, entrepreneurs' motives may not only be related to a desire to seek for private rewards, but also to increase social welfare. This process presents some similarities to the concept of “coordination” in economic models, but, due to our peculiar definition of the entrepreneurial decisions, this coordination activity is grounded on the capability to deal with uncertainty that other agents are not able to handle. As commonly occurs, private and social benefits are unlikely to be aligned when we talk about entrepreneurs (Casson and Wadeson, 2007a).

\subsection{Assumptions on markets}

Our definition implies that entrepreneurs are active "market-makers" who create new markets by introducing new products (Casson, 1982; 1997). The assumptions on the markets where entrepreneurs operate are shaped by this fact. The entrepreneurs' environment is 
volatile due to transitory or temporary shocks, and new opportunities are constantly being created. As seen above, an opportunity may arise because of a change in demand conditions, or a change in supply conditions, or a change in whatever (as transport, communication or institutional arrangements) makes it easier to match supply to demand (Casson and Wadeson, 2007a). In the absence of the entrepreneur there would be no markets at all: the volatility of consumer demand for novelty is important in generating a demand for entrepreneurship.

Focusing on the entrepreneur as a market-maker points out some interesting insights on information and uncertainty. Industrial organization assesses a crucial role for the industrial structure, whereas finance looks at the uncertain matching between market conditions, and labour economics focuses on individuals' labour markets and possible career patterns. The entrepreneur is not merely a producer who supplies a product, and the presence of a pre-existing market is incompatible with our definition. The only assumption we make about markets is that they are endogenously determined by the mutual interplay of demand and supply and the specific market structure that arises and the way that entrepreneurial rewards are determined are uncertain ex ante. Furthermore, it is necessary to specify all the markets we need to model: the market originated by the new good derives from an opportunity exploited by the entrepreneur and gives rise to a market for entrepreneurship, but also business investments and labour markets are affected by this process.

\section{Conclusions}

The purpose of this paper is to build up an integrated investigation of the entrepreneurial decision. We follow Casson (1982) in defining the entrepreneur as characterized by the exercising of judgemental decision, and consequently able to handle uncertainty and acquire costly information. In this perspective, literature in the entrepreneurship field may be 
insufficient to generate a comprehensive framework of judgement, uncertainty and information. Thus, different strands of the literature within the economics approach have been reviewed. We aim at formulating simple and general assumptions on entrepreneurs' features, acts and motives that can be common to studies on entrepreneurship in industrial organization, financial economics and labour economics, although each approach presents its own peculiarities. When the entrepreneur's judgemental decision is depicted as entry, knowledge about markets, competitors and industries is crucial. When it deals with an investment decision, uncertainty regards the profitability and the timing of exercising the option to invest in a real business. When it is framed as a career choice, knowledge about the labour market and personal abilities and attitude is required.

\section{References}

Abel, A.B. (1982), "Dynamic effect of temporary and permanent tax policies in a q model of investment”, Journal of Monetary Economics, Vol. 9, pp. 353-373.

Abelson, R.P. and Levi, A. (1985), “Decision making and decision theory”, In Lindzey, G. and Arenson, B. (Eds), The Handbook of Social Psychology, $3^{\text {rd }}$ edition, Random House, New York, NY, pp. 231-309.

Abernathy, W. and Utterback, J. (1978), “Patterns of industrial innovation”, Technology Review, Vol. 80, pp. 41-47.

Acs, Z.J. and Audretsch, D.B. (2003), Handbook of Entrepreneurship Research. An Interdisciplinary Survey and Introduction. Kluver Academic Publishers, Dordrecht.

Audretsch, D. (1995), Innovation and Industry Evolution, The MIT Press, Cambridge, MA. Audretsch, D. (2002), “Entrepreneurship: A Survey of the Literature”, Paper Prepared for the European Commission, Enterprise Directorate General. 
Blanchflower, D.G. and Oswald, A.J. (1998), “What makes an entrepreneur?”, Journal of Labor Economics, Vol. 16, pp. 26-60.

Brock, W.A. and Evans, D.S. (1989), “Small business economics”, Small Business Economics: An International Journal, Vol. 1, pp. 7-20.

Brockhaus, R.H (1980), "Risk taking propensity of entrepreneurs", The Academy of Management Journal, Vol. 23 No. 5, pp. 509-520.

Bygrave, W.D. and Hofer, C.W. (1991), “Theorizing about entrepreneurship”, Entrepreneurship Theory and Practice, Vol. 16 No. 2, pp. 13-22.

Bull, I., Thomas, H. and Willard, G. (Eds) (1996), Entrepreneurship: Perspectives on Theory Building, Elsevier, London.

Camerer, C. F. and Lovallo, D. (1999), “Overconfidence and excess entry: An experimental approach”, American Economic Review, Vol. 89 No. 1, pp. 306-318.

Campbell, C. A. (1992), “A decision theory model for entrepreneurial acts”, Entrepreneurship: Theory and Practice, Vol. 17, pp. 21-27.

Cantillon, R. (1759), Essai sur la Nature du Commerce in Général.

Casson, M.C. (1982), The Entrepreneur. An Economic Theory. Edward Elgar Publishing, Cheltenham.

Casson, M.C. (Ed.) (1990), Entrepreneurship, Elgar, Aldershot.

Casson, M.C. (1997), “Entrepreneurial networks in international business”, Business and Economic History, Vol. 26 No.2, pp. 3-17.

Casson, M.C. (2003), The Entrepreneur. An Economic Theory. Second Edition, Edward Elgar Publishing, Northampton, MA.

Casson, M.C. (Ed.) (2006), The Oxford Handbook of Entrepreneurship, Oxford University Press, Oxford; New York, NY. 
Casson, M.C. (Ed.) (2010), Entrepreneurship: Theory, Network, History, Edward Elgar, Cheltenham; Northampton, MA.

Casson, M.C. and Wadeson, N. (2007a), “Entrepreneurship and macroeconomic performance”, Strategic Entrepreneurship Journal, Vol. 1 No. 3-4, pp. 239-262.

Casson, M.C. and Wadeson, N. (2007b), “The discovery of opportunities: Extending the economic theory of the entrepreneur”, Small Business Economics, Vol. 28 No. 4), pp. 285-300.

Cooper, A.C., Woo C.J. and Dunkelberg, W.C. (1988), “Entrepreneurs’ perceived chances for success”, Journal of Business Venturing, Vol. 2, pp. 97-108.

Das, S., Roberts, M.J., and Tybout, J.R. (2007), “Market entry costs, producer heterogeneity, and export dynamics”, Econometrica, Vol. 75 No. 3, pp. 837-873.

Dixit, A.K. (1989), “Entry and exit decisions under uncertainty”,. Journal of Political Economy, Vol. 97 No. 3, pp. 620-638.

Dixit, A.K. and Pindyck, R.S. (1994), Investment Under Uncertainty, Princeton University Press, Princeton, NJ.

Douglas, E.J. and Shepherd, D.A. (2002), "Self-employment as a career choice: Attitudes, entrepreneurial intentions, and utility maximization” Entrepreneurship: Theory and Practice, Vol. 26 No. 3, pp. 81-90.

Eisenhauer, J.G. (1995), “The entrepreneurial decision: Economic theory and empirical evidence” Entrepreneurship: Theory and Practice, Summer, pp. 67-79.

Eisner, R. and Strotz, R.H. (1963), “Determinant of business investment”, in Commission on Money and Credit, Impacts of Monetary Policy, Prentice Hall, Englewood Cliffs, NJ.

Evans, D. and Leighton, L. (1989), “Some empirical aspects of entrepreneurship”, American Economic Review, Vol. 79, pp. 519-535. 
Fairlie, R.W. and Meyer, B.D. (2000), “Trends in self-employment among white and black men during the twentieth century”, Journal of Human Resources, Vol. 35 No. 4, pp. 643-669.

Gartner, W.B. (1990), “What are we talking about when we talk about entrepreneurship?”, Journal of Business Venturing, Vol. 5 No. 1, pp. 15-28.

Glancey, K.S. and McQuaid, R.W. (2000), Entrepreneurial Economics, Macmillan Press, London.

Grenadier, S.R. and Wang, N. (2007), “Investment under uncertainty and time-inconsistent preferences”, Journal of Financial Economics, Vol. 84 No. 1, pp. 2-39.

Gunderson, G. (1990), “Thinking about entrepreneurs: Models, assumptions and evidence”, in Kent, C.A. (Ed), Entrepreneurship Education: Current developments, future directions, Greenwood Publishing Group, Westport, CT.

Hamilton, B.H. (2000), “Does entrepreneurship pay? An empirical analysis of the returns to self-employment”, Journal of Political Economy, Vol. 108 No. 3, pp. 604-631.

Hogarth, R.M. and Karelaia, N. (2010), “The attraction of uncertainty: Interactions between skill and levels of uncertainty in market-entry games”, Journal of Risk and Uncertainty, Vol. 41 No. 2, pp. 141-166.

Horvath, M., Schivardi, F. and Woywood, M. (2001), “On industry life-cycles: Delay, entry, and shake-out in beer brewing”, International Journal of Industrial Organization, Vol. 19 No. 7, pp. 1023-1052.

Hughes, A. (1992), “Big business, small business and the 'Enterprise Culture’”, in Michie, J. (Ed.), The Economic Legacy, 1979-1992, Academic Press, London.

Huisman, K.J.M., Kort, P.M., Pawlina, G., and Thijssen, J.J. (2003), “Strategic investment under uncertainty: Merging real options with game theory”, Discussion Paper 06, Tilburg University, Tilburg, The Netherlands. 
Jorgenson, D.W. (1963), “Capital theory and investment behaviour”, American Economic Review, Vol. 53 No. 2, pp. 247-259.

Jovanovic, B. (1982), "Selection and the evolution of industry", Econometrica, Vol. 50, pp. 649-670.

Jovanovic, B. and MacDonald G. (1994), “The life cycle of a competitive industry”, Journal of Political Economy, Vol. 102, pp. 322-347.

Kahneman, D., Slovic P., and Tversky, A. (Eds.), (1982), Judgment under Uncertainty: Heuristics and Biases, Cambridge University Press, Cambridge.

Kanbur, S.M.R. (1982), “Entrepreneurial risk-taking, inequality, and public policy: An application of inequality decomposition analysis to the general equilibrium effect of progressive taxation”, Journal of Political Economy, Vol. 90, pp. 1-21.

Kirzner, I. (1973), Competition and Entrepreneurship, University of Chicago Press, Chicago, IL.

Kirzner, I.M. (1983), “Entrepreneurship and the future of capitalism”, in Bachman, J. (Ed.), Entrepreneurship and the Outlook for America. The Free Press, New York, NY.

Klepper, S. (1996), “Entry, exit, growth and innovation over the product life cycle, American Economic Review, Vol. 86, pp. 562-583.

Knight, F.H. (1921), Risk, Uncertainty and Profit, Harper and Row, New York, NY.

Krueger, N.F., Reilly, M.D. and Carsrud, A.L. (2000), "Competing models of entrepreneurial intentions”, Journal of Business Venturing, Vol. 15 No. 5-6, pp. 411432.

Lambrecht, B. and Perraudin, W. (2003), “Real options and pre-emption under incomplete information”, Journal of Economic Dynamics \& Control, Vol. 27, pp. 619-643.

Lazear, E.P. (1981), “Agency, earning profiles, productivity, and hours restrictions”, American Economic Review, Vol. 71, pp. 606-620. 
Lazear, E.P. and Moore, R.L. (1984), “Incentives, productivity, and labour contracts”, Quarterly Journal of Economics, Vol. 99, pp. 275-296.

Loasby, B.J. (1976), Choice, Complexity and Ignorance, Cambridge University Press, Cambridge.

MacDonald, G.M. (1988), “The economics of rising stars”, American Economic Review, Vol. 78, pp. 155-166.

Mises, L. (1949), Human Action, William Hodge, London.

Moore, D. A. and Cain, D. M. (2005), “Overconfidence and underconfidence: When and why people underestimate (and overestimate) the competition”, Working Paper, 2003E76, Tepper School of Business, Carnegie Mellon University, Pittsburg.

Moore, D.A., Oesch, J.M. and Zietsma, C. (2007), "What competition? Myopic self-focus in market-entry decisions”, Organization Science, Vol. 18 No. 3, pp. 440-454.

Mueller, D. (1991), "Entry, exit and the competitive process", in Geroski, P. A. and Schwalbach, J. (Eds), Entry and Market Contestability: An International Comparison, Blackwell, Oxford.

Mussa, M. (1977), "External and internal adjustment costs and the theory of aggregate and firm investment”. Econometrica, Vol. 44 No. 174, pp. 163-178.

Nelson, R. and Winter, S. (1982), An Evolutionary Theory of Economic Change, Harvard University Press, Cambridge, MA.

O'Brien, J.P., Folta, T.B., and Johnson, D.R. (2004), “A real options perspective on entrepreneurial entry in the face of uncertainty”, Managerial and Decision Economics, Vol. 24 No. 8, pp. 515-533.

Osborne, A. (1976), “The welfare effects of black capitalists on the black community”, Review of Black Political Economy, Vol. 6, pp. 424-432. 
Parker, S.C. (1996), “A time series model of self-employment under uncertainty”, Economica, Vol. 63 No. 251, pp. 459-475.

Pindyck, R.S. (1991), “Irreversibility, uncertainty, and investment”, Journal of Economic Literature, Vol. XXIX, pp. 1110-1148.

Quinn, J. (1980), “Labor force participation patterns of older self-employed workers”, Social Security Bulletin, Vol. 43, pp. 17-28.

Rees, H. and Shah, A. (1986), “An empirical analysis of self-employment in the U.K.”. Journal of Applied Econometrics, Vol. 1, pp. 95-108.

Rosen, S. (1981), “The economics of superstars”, American Economic Review, Vol. 71, pp. 845-858.

Roy, A.D. (1951), "Some thoughts on the distribution of earnings", Oxford Economic Papers, Vol. 3, pp. 135-146.

Schjoedt, L. and Shaver, K.G. (2007), “Deciding on an entrepreneurial career: A test of the push and pull hypotheses using the PSED data”, Entrepreneurship Theory \& Practice, Vol. 31 No. 6, pp. 733-752.

Schumpeter, J.A. (1942), Capitalism, Socialism and Democracy, Unwin, London.

Schumpeter, J.A. (1954), History of Economic Analysis, Oxford University Press, New York, NY.

Shackle, G.L.S (1970), Expectations, Enterprise and Profit, George Allen \& Unwin, London.

Shane, S. (2003), A General Theory of Entrepreneurship: The Individual-Opportunity Nexus, Edward Elgar, Cheltenham.

Simon, H.A. (1983), “Search and reasoning in problem solving”, Artificial Intelligence, Vol. 21, pp. 7-29. 
Storey, D. (Ed.) (2000), Small Business: Critical Perspectives on Business and Management, Routledge, London.

Swedberg, R. (Ed.) (2000), Entrepreneurship: The Social Science View, Oxford University Press, New York, NY.

Szpiro, G.S. (1986), "Measuring risk aversion: An alternative approach”, The Review of Economics and Statistics, Vol. 68 No. 1, pp. 156-159.

Tobin, J. (1969), “A general equilibrium approach to monetary theory”, Journal of Money, Credit and Banking, Vol. 1 No. 1, pp. 15-29.

Westhead, P. and Wright, M. (Eds.) (2000), Advances in Entrepreneurship, Edward Elgar, Cheltenham. 